\title{
Hydrolysis of bioactive isoflavone in soymilk fermented with $\beta$-glucosidase producing lactic acid bacteria from local fermented foods of Indonesian
}

\author{
Sumarna \\ Department of Food Science and Biotechnology, \\ Technical Implementation Unit for Development of Chemical Engineering Processes, \\ Indonesian Institute of Sciences, Yogyakarta, Indonesia. \\ Email: marna_smn@yahoo.com
}

Received 9 April 2009; received in revised form 23 July 2009; accepted 30 July 2009

\begin{abstract}
This study investigated the possible application of $\beta$-glucosidase producing lactic acid bacteria isolated from local fermented foods as a functional starter culture to obtain the bioactive isoflavones, genistein and daidzein, in fermented soymilk. Seven strains of bacteria, Lactobacillus plantarum pentosus SMN 001, Lactobacillus casei subsp rhamnosus FNCC 098, Lactobacillus casei subsp rhamnosus FNCC 099, Lactobacillus casei subsp rhamnosus FNCC 113, Lactobacillus delbrueckii subsp. delbrueckii FNCC 045, Lactobacillus plantarum SMN 025 and Lactobacillus plantarum pentosus FNCC 235 exhibited variable $\beta$-glucosidase activity. L. plantarum SMN 025 and L. casei subsp rhamnosus FNCC 098 exhibited the highest $\beta$-glucosidase activity of 0.653 and $0.643 \mathrm{U} / \mathrm{mL}$ respectively. Acid development, viable populations, $\beta$-glucosidase activity and quantification of isoflavone using HPLC were performed at $0,6,12,18,24$ and $30 \mathrm{~h}$ of incubation at $41^{\circ} \mathrm{C}$. Seven $\beta$-glucosidase-producing strains are able to increase aglycones in fermented soymilk, however, each of the strain produces significantly different bioconversion $(p<0.05)$ of the glucoside isoflavones into their bioactive aglycones. During this fermentation period, with $L$. plantarum SMN 025, and L. casei subsp rhamnosus FNCC 098, the high level reduced from $150.62 \mu \mathrm{g} / \mathrm{mL}$ (at $24 \mathrm{~h}$ ) to $142.58 \mu \mathrm{g} / \mathrm{mL}$ and from $150.62 \mu \mathrm{g} / \mathrm{mL}$ (at $24 \mathrm{~h}$ ) to 144.71 $\mu \mathrm{g} / \mathrm{mL}$, respectively. The indicate that two $\beta$-glucosidase producing lactic acid bacteria have great potential for enrichment of bioactive isoflavones in soymilk fermentation.
\end{abstract}

Keywords: lactic acid bacteria, isoflavone contents, $\beta$-glucosidase, soymilk

\section{INTRODUCTION}

Isoflavones are phytochemicals present in leguminous plants, especially in soybeans. Soy isoflavones have been implicated in health benefits, including the potential to reduce the risk of age-related and hormone-related diseases including cancer, menopausal symptoms, cardiovascular disease, and osteoporosis (Jacobsen et al., 1998; FDA, 1999; Gerhauser et al., 2003; Hermansen et al., 2003; Omoni et al., 2005). Researches indicate that differences in the chemical structure of isoflavones may result in variable bioavailabilities in biological systems (Brown, 1998; Xu et al., 1994). In general, isoflavones in soybeans exist mainly as glucoside forms and rarely as aglycone forms unless they have been fermented (Wang and Murphy, 2006). It has been reported that certain intestinal bacteria play major roles in the hydrolysis of isoflavone glucosides and promote their absorption in the intestine (Setchell et al., 2002). Biotransformation and the production of metabolites of isoflavones in the intestinal tract are highly dependent on the nature of intestinal microflora

In soybeans, most isoflavones exist as glycoside, acetylglycoside, and malonylglycoside forms and, to a lesser extent, in the form of aglycones. However, it is recognized that the readily bioavilable isoflavones are aglycones rather than glycosides. The glucoside conjugates of isoflavones are converted into aglycones during soybean processing by the effect of $\beta$-glucosidase. $\beta$-glucosidase is considered to be key enzyme for the conversion of isoflavone form in fermented soybean foods. We have shown $\beta$-glucosidase to be effective in converting isoflavone glycoside to aglycones (Pandjaitan et al., 2000a; 2000b). $\beta$-glucosidase has superior activity for hydrolyzing acetylglycoside and malonylglycoside isoflavones. If $\beta$-glucosidase can effectively convert acetylglycoside and malonylglycoside to their aglycones, it can lead to an enrichment of isoflavone aglycones in soy food such as soy milk fermented. Depending on processing technique, soybean products present different forms and concentrations of isoflavones. Fermented products contain higher levels of aglycones forms (Coward et al., 1998 and Wang and Murphy, 2006). Lactic acid fermentation (Wang and Murphy, 2006) and pre-soaking treatments during processing activate the enzymatic process of $\beta$-glucosidase (Matsuda et al., 1994 Matsuura et al., 1993; 1998). Wang et al., 1996; 2006) observed that the optimum $\mathrm{pH}$ for production of aglycones, daidzein and genistein, in soymilk was around 6.0 at $50{ }^{\circ} \mathrm{C}$ temperature. Two isoforms of $\beta$-glucosidase 
brought nearly all the hydrolyzing action into daidzin and genistin (Matsuura et al., 1993). The enzyme showed optimum activity at $\mathrm{pH} 4.5$ and $45^{\circ} \mathrm{C}$, and its $\mathrm{pH}$ range of action was 3.2-7.0. The isoflavones daidzein and genistein occur naturally in most soyfoods, conjugated almost exclusively to sugars.

Probiotic microorganisms possess $\beta$-glucosidase, $\beta$ galactosidase and $\alpha$-galactosidase (Tochikura et al., 1986), which play an important role in the hydrolysis isoflavone glycosides to the bioavailable aglycones forms. Commercial $\beta$-glucosidases have been used in biotransformation of isoflavone glycosides (Park et al., $2002 ; 2003)$ and $\beta$-glucosidase from Bifidobacterium have been used in hydrolysing the $\beta-1,6$-glycoside bonds in order to increase the concentration of bioactive isoflavone aglycones in soymilk (Tsangalis et al., 2002; 2003). Microorganisms possess endogenous $\beta$-glucosidases which can be utilised to hydrolyse predominant isoflavone glucosides in soymilk to improve biological activity. It has been reported that probiotic organisms including Bifidobacterium, Lactobacillus acidophilus and L. casei increased the concentration of bioactive isoflavone aglycones in soymilk during fermentation. It has been reported that many bifidobacteria and some other lactic acids (Bordignon et al., 2004; Pyo et al., 2005; Chien et al., 2006) hydrolyse isoflavone glycosides into corresponding aglycones. Bifidobacterium breve, Bifidobacterium bifidum and $L$. casei subsp. rhamnosus strains produced the yogurt-like fermented soybean milk containing high concentrations of isoflavone aglycones. Therefore, our objectives were to examine the effectiveness of $\beta$ glucosidase producing lactic acid bacteria isolated from local fermented foods as a functional starter cultures to increases the bioactive isoflavones in fermented soymilk.

\section{MATERIALS AND METHODS}

\section{Materials and chemicals used}

Soybeans (Glycine max. L. Merr) of cultivar wilis, highperformance liquid chromatography (HPLC) grade methanol, acetonitrile, and water were purchased from Fisher Scientific (Hanover Park, IL). The aglycone standards of genistein, daidzein and glycitein as well as flavone were purchased from Sigma (Merck, Oxoid), while the $\beta$-glucoside standards of genistin, daidzin and glycitin as well as daidzein were purchased from Alfa Chemical. Genistein, genistin, flavone, daidzein were prepared in HPLC grade methanol, and daidzin, glycitein and glycitin were prepared in ethanol due to their varied solubility characteristics. All others chemicals and reagents were of analytical grade.

\section{Strains and culture conditions}

Sevens strains of lactic acid bacteria were isolated from local fermented foods such as fermented cassava (gatot, and growol), tempeh, bamboo shoot, muromi ketchup, Yoghurt L. plantarum pentosus SMN 001, L. casei subsp. rhamnosus FNCC 098, L. casei subsp. rhamnosus FNCC 099, L. casei subsp. rhamnosus FNCC 113, L. delbrueckii subsp. delbrueckii FNCC 045, L. plantarum SMN 025 and L. plantarum pentosus FNCC 235 (Sumarna, 2008) were obtained from food and nutrition culture collection Centre for Food and Nutrition studies, Gadjah Mada University. Culture stock were kept in $10 \%$ glycerol and $10 \%$ skim milk with the ratio $1: 1$ kept in sterile $1.5 \mathrm{~mL}$ polyethylene srew cap tubes at $-40^{\circ} \mathrm{C}$. The strains were rejuvenated in MRS broth (Merck, Oxoid) at $37^{\circ} \mathrm{C}$ for $24 \mathrm{~h}$.

\section{Soymilk preparation}

Soybean grains $(500 \mathrm{~g})$ were soaked in cold water for 12 $\mathrm{h}$ at room temperature $\left(27^{\circ} \mathrm{C}\right)$. After soaking, water was discarded and the grains were then ground in a blender, for $3 \mathrm{~min}$, in $4000 \mathrm{~mL}$ of hot water at $60{ }^{\circ} \mathrm{C}$. Soymilk was extracted by filtration through a cotton cloth. The slurry was cooked for $10 \mathrm{~min}$, filtered and boiled at $70{ }^{\circ} \mathrm{C}$ for 30 $\min$.

\section{Fermentation of soymilk with lactic acid bacteria isolated from local fermented foods}

Two sets of 6 glass bottles each containing $300 \mathrm{~mL}$ sterile soymilk were aseptically inoculated with active culture of L. plantarum pentosus SMN 001, L. casei subsp. rhamnosus FNCC 098, L. casei subsp. rhamnosus FNCC 099, L. casei subsp. rhamnosus FNCC 113, L. delbrueckii subsp. delbrueckii FNCC 045, L. plantarum SMN 025, and L. plantarum pentosus FNCC 235 strains at $5 \%(\mathrm{v} / \mathrm{v})$ and incubated at $41^{\circ} \mathrm{C}$ for $24 \mathrm{~h}$. The bottles were labeled 0,6 , $12,18,24$, and $30 \mathrm{~h}$ in order to facilitate withdrawing of aliquots at $0,6,12,18,24$, and $30 \mathrm{~h}$ of fermentation. Aliquots of $50 \mathrm{~mL}$ from each of the 6 bottles were taken at $0,6,12,18,24$, and $30 \mathrm{~h}$ of incubation. Each aliquot was divided into 20 and $30 \mathrm{~mL}$ portions in sterile $50 \mathrm{~mL}$ screw top falcon tubes. The $20 \mathrm{~mL}$ portions were used for determination of $\beta$-glucosidase activity, and $\mathrm{pH}$, and enumeration of cell counts, whereas the $30 \mathrm{~mL}$ portions were freeze dried for the analysis of isoflavones using high-performance liquid chromatography (HPLC)

\section{$\mathrm{pH}$ measurements}

Changes in $\mathrm{pH}$ were monitored during fermentation of soymilk at $0,6,12,24$, and $30 \mathrm{~h}$ using a pH meter (HANNA Instruments).

\section{Enumeration of bacterial population}

Cell populations of $L$. plantarum pentosus SMN 001, $L$. casei subsp. rhamnosus FNCC 098, L. casei subsp. rhamnosus FNCC 099, L. casei subsp. rhamnosus FNCC, 113, L. delbrueckii subsp. delbrueckii FNCC 045, L. plantarum SMN 025 and L. plantarum pentosus FNCC 235 was determined as described previously. Briefly, $1 \mathrm{~g}$ of each fermented soymilk sample was added to $9 \mathrm{~mL}$ of sterile $0.15 \%(\mathrm{w} / \mathrm{v})$ bacteriological peptone (Oxoid) and 
water diluent and vortexed for $30 \mathrm{~s}$. The resulting suspension was serially diluted in sterile $0.15 \%(\mathrm{w} / \mathrm{v})$ peptone water (Oxoid) and $1 \mathrm{~mL}$ of the appropriate dilution was used for selective enumeration by the pour plate technique. The cell growth of each organism was assessed by enumerating bacterial population after 6,12 , 24, 36 and $48 \mathrm{~h}$ of fermentation of soymilk on MRS agar (Amyl media). Anaerobic jars and gas generating kits were used for creating anaerobic conditions. Plates containing 25 - 250 colonies were counted and recorded as colony forming units (CFU) per gram of the fermented soymilk.

\section{Analysis of $\beta$-glucosidase activity soymilk}

Seven strains of lactic acid bacteria were each inoculated in $50 \mathrm{~mL}$ soymilk, and incubated at $37{ }^{\circ} \mathrm{C}$ for $30 \mathrm{~h}$ and screening for $\beta$-glucosidase activity was conducted at 0 , $12,18,24$, and $30 \mathrm{~h}$ of incubation. Based on $\beta$ glucosidase activity, seven strains were selected for further enzymatic assay. The strains were activated in MRS broth by inoculating $1 \%$ level at $41^{\circ} \mathrm{C}$ for $24 \mathrm{~h}$. The 5 inoculations were done in sterile soymilk from which $5 \%$ $\mathrm{w} / \mathrm{v}$ of each active culture was inoculated in $300 \mathrm{~mL}$ of 6 bottles of soymilk. Fifty milliliters of aliquot was withdrawn aseptically from each sample at $0,6,12,18,24$, and $30 \mathrm{~h}$ of incubation and $\beta$-glucosidase activity was determined using modified method of Tsangalis et al. (2002) by measuring the rate of hydrolysis of $p$-nitrophenyl- $\beta$-Dglucopiranoside $1 \mathrm{mM}(\rho \mathrm{NPG})$. One thousand microliters of $5 \mathrm{mM}(\rho \mathrm{NPG})$ prepared in $100 \mathrm{mM}$ sodium phosphate buffer ( $\mathrm{pH} 7$ ) was added to $10 \mathrm{~mL}$ of each aliquot and incubated at $41^{\circ} \mathrm{C}$ for $30 \mathrm{~min}$ (Scalabrini et al., 1998). Five hundred microliters of $1 \mathrm{M}$ cold sodium carbonate was added to stop the reaction. The aliquots were then placed in $1.8 \mathrm{~mL}$ eppendorf centrifuge tubes followed by centrifugation $(14000 \times g)$ for 30 min using an eppendorf centrifuge (model 5415). The amount of $\rho$-nitrophenol released was measured using a spectrophotometer at 420 $\mathrm{nm}$. One unit of the enzyme activity was defined as the amount of $\beta$-glucosidase that released 1 micromole of $\rho$ nitrophenol from substrate $\rho \mathrm{NPG}$ per $\mathrm{mL}$ per min under assay conditions. The specific activity was expressed as a unit of enzyme per microgram of the protein. The protein concentration was determined by a modified version of the Lowry method. The supernatant was filtered through a $0.45 \mu \mathrm{m}$ filter membrane to filter out $\rho$-nitrophenol. The $\rho$ NPG substrate and $\rho$-nitrophenol were purchased from Sigma Chemical Co. Jakarta, Indonesia.

\section{Extraction of isoflavones for HPLC analysis}

The extraction of isoflavones, including malonyl-, acetyl-, $\beta$-glycosides, and aglycones from fermented and nonfermented soymilk was performed in triplicate, using a modified version of the method described by Tsangalis et al. (2002). A $1 \mathrm{~g}$ freeze-dried sample was added to $50 \mathrm{~mL}$ of methanol in a $150 \mathrm{~mL}$ round bottom flask and refluxed on a heating mantle for $1 \mathrm{~h}$. The mixture was then filtered through a Whatman No. 1 filter paper into a $100 \mathrm{~mL}$ volumetric flask. The remaining dried soy matter was washed with the filtered portion and then refiltered into the same flask. A $5 \mathrm{~mL}$ aliquot was mixed with $60 \mu \mathrm{L}$ of internal standard flavone solution $(10 \mathrm{mg} / 50 \mathrm{~mL})$ and dried under a stream of nitrogen using a Techne Sample Concentrator. The resultant dried matter was then resuspended in $1 \mathrm{~mL}$ of $10 \mathrm{mM}$ ammonium acetate buffer (containing $0.1 \%$ trifluoro-acetic acid) and acetonitrile (50:50) solution and centrifuged $(14,000 \times g)$ for $30 \mathrm{~min}$ using an Eppendorf centrifuge (model 5415C) to precipitate undissolved matter prior to transferring to HPLC vials.

\section{HPLC analysis of isoflavones}

HPLC gradient elution for isolating the isoflavones for detection was acetonitrile (Solvent A) and $10 \mathrm{mM}$ ammonium acetate buffer containing $0.1 \%$ trifluoro-acetic acid (Solvent B) set at a flow rate of $1 \mathrm{~mL} / \mathrm{min}$ (Setchel, 1998). After $20 \mu \mathrm{L}$ injection of sample or isoflavone standard into the column, solvent B was set at $100 \%$ for 2 $\mathrm{min}$, reduced to $60 \%$ over $22 \mathrm{~min}$ and finally $100 \%$ for 5 min prior to the next injection. A diode array UV-visible detector was set at dual wavelengths of $260 \mathrm{~nm}$ to detect the malonyl-, acetyl-, and $\beta$-glycosides, aglycones, and the flavone. Single standards were prepared for identification of peak. Malonyl- and acetyl-glycoside conjugates were quantified with respect to their $\beta$ glycoside equivalent response factors and corrected according to molecular weight. Isoflavone concentrations were calculated back to wet basis ( $\mu \mathrm{g}$ isoflavones $/ \mathrm{mL}$ soymilk).

\section{Statistical analysis}

The enzyme activity in soymilk and isoflavone concentrations during incubation were obtained in triplicate on two occasions and presented as means \pm standard error of 3 replicates. The analysis was conducted using one-way analysis of variance (ANOVA) and $95 \%$ confidence levels, using Microsoft Excel. ANOVA data with a $p<0.05$ was classified as statistically significant.

\section{RESULTS AND DISCUSSION}

Proximate composition and total isoflavone contents of local developed and cultivated soybean variety wilis, soymilk.

Results of analysis Proximate composition and total isoflavone contents are given in Table 1. 
Table 1: Proximate composition (g/100g dry weight) and total isoflavone contents

\begin{tabular}{lll}
\hline Composition & Wilis soybeans & Soymilk \\
\hline Moisture & $11.0 \pm 0.40$ & $88.90 \pm 1.80$ \\
Protein & $34.0 \pm 1.00$ & $3.6 \pm 0.12$ \\
Fat & $21.6 \pm 0.20$ & $1.3 \pm 0.03$ \\
Carbohydrates & $28.1 \pm 1.20$ & $2.08 \pm 0.01$ \\
Raffinose (mg) & $987 \pm 2.80$ & $850 \pm 1.30$ \\
Stachyose (mg) & $475 \pm 1.50$ & $350 \pm 1.10$ \\
Ash & $2.97 \pm 0.10$ & $0.46 \pm 0.01$ \\
Glucoside & & \\
Daidzin & $57.02 \pm 3.12$ & $27.06 \pm 1.12$ \\
Genistin & $62.64 \pm 3.14$ & $32.65 \pm 1.14$ \\
Glycitin & $21.03 \pm 0.47$ & $11.03 \pm 0.47$ \\
Malonylglucoside & & \\
Daidzin & $27.06 \pm 2.21$ & $7.06 \pm 0.12$ \\
Genistin & $11.65 \pm 1.14$ & $5.65 \pm 0.14$ \\
Glycitin & $13.03 \pm 1.18$ & $3.03 \pm 0.12$ \\
Acetylglucoside & & \\
Daidzin & $24.26 \pm 2.42$ & $14.26 \pm 0.42$ \\
Genistin & $22.56 \pm 1.74$ & $12.56 \pm 0.74$ \\
Glycitin & $14.33 \pm 1.31$ & $9.33 \pm 0.31$ \\
Aglycone & & $15.16 \pm 0.32$ \\
Daidzein & $7.36 \pm 0.32$ & $8.46 \pm 0.44$ \\
Genistein & $3.46 \pm 0.44$ & $4.37 \pm 0.13$ \\
Glycitin & $2.37 \pm 0.13$ & $150.62 \pm 5.43$ \\
\hline Total & $266.77 \pm 5.43$ & \\
\hline
\end{tabular}

The $\mathrm{pH}$ change and growth of with strains lactic acid bacteria were isolated from local fermented foods

All the seven strains showed lowering $\mathrm{pH}$ of culture media and production of lactic acid are essential for manufacturing soygurt. In the soymilk, most strains tested could lower $\mathrm{pH}$ and produce lactic acid. However, $L$. plantarums SMN 025 and L. casei subsp. rhamnosus FNCC 098 showed lowering pH of the culture medium or production of lactic acid, and the highest viable counts during fermentation occurred at $24 \mathrm{~h}$ at $41^{\circ} \mathrm{C}$ in the soymilk. Changes in the $\mathrm{pH}$ and population cell of with strains lactic acid bacteria were isolated from local fermented foods in soymilk during fermentation at $0,6,12$, 18,24 , and $30 \mathrm{~h}$ at $41^{\circ} \mathrm{C}$ are shown in Figure 1 and 2. Subsequently, fermentation at $24 \mathrm{~h}$ the populations declined slowly for all strains growth. The initial $\mathrm{pH}$ of all soymilk samples after inoculation was 6.4 . At $41^{\circ} \mathrm{C}$, the fastest $\mathrm{pH}$ decline was observed in soymilk with culture $L$. plantarums SMN 025 and $L$. casei subsp. rhamnosus FNCC 098. After $24 \mathrm{~h}$ of fermentation, the $\mathrm{pH}$ values of soymilk reached 3.7.and 3.8, respectively. Seven strains of lactic acid bacteria tested in this study could grow in the soybean milk medium with a maximum viable cell count greater than $10^{9} \mathrm{CFU} / \mathrm{mL}$.

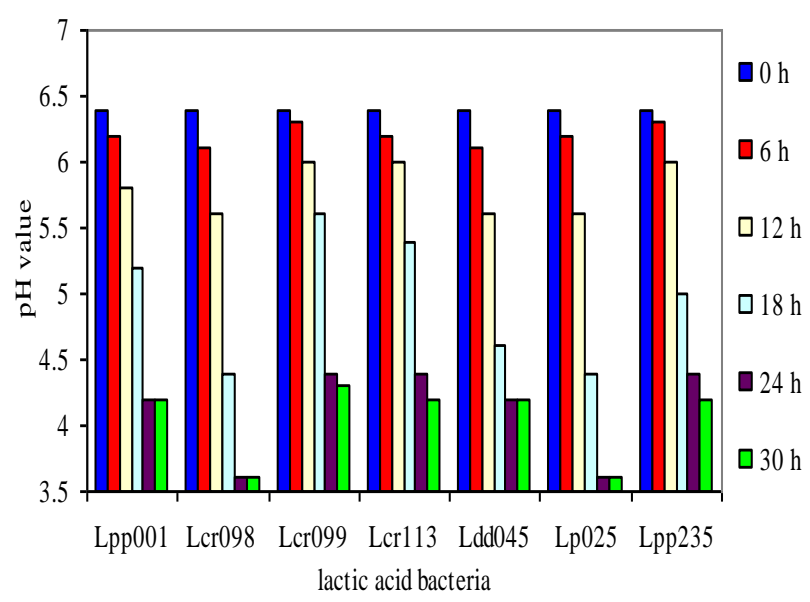

Figure 1: $\mathrm{pH}$ changes in soymilk during fermentation with each of the seven strains lactic acid bacteria at $41^{\circ} \mathrm{C}$ (Lpp001 $=$ L. plantarum pentosus SMN 001; Lcr098 $=$ L. casei subsp. rhamnosus FNCC 098; Lcr099=L. casei subsp. rhamnosus FNCC 099; Lcr113=L. casei subsp. rhamnosus FNCC 113; Ldd045=L. delbrueckii subsp. delbrueckii FNCC 045; Lp025=L. plantarum SMN 025, and Lpp235=L. plantarum pentosus FNCC 235)

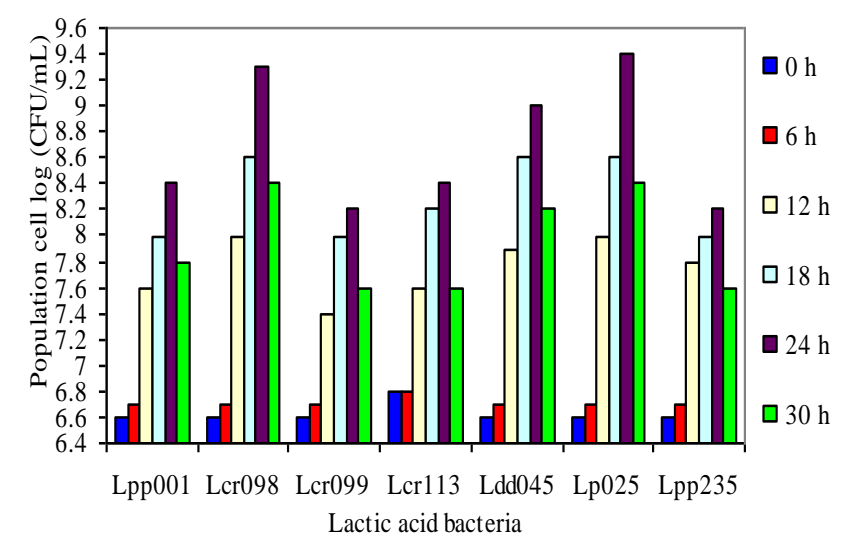

Figure 2: Population cell in soymilk during fermentation with each of the seven strains lactic acid bacteria at $41^{\circ} \mathrm{C}($ Lpp001 $=L$. plantarum pentosus SMN 001; Lcr098=L. casei subsp. rhamnosus FNCC 098; Lcr099=L. casei subsp. rhamnosus FNCC 099; Lcr113=L. casei subsp. rhamnosus FNCC 113; Ldd045=L. delbrueckii subsp. delbrueckii FNCC 045; Lp025=L. plantarum SMN 025, and Lpp235=L. plantarum pentosus FNCC 235) 


\section{$\beta$-Glucosidase activity in fermented soymilk}

Due to the fact that these glucosidase enzymes exist intercellularly in crude forms, assaying for a specific enzyme required the use of a specific substrate to determine the glucosidase enzyme potential of seven strain. Due to our interest in $\beta$-glucosidase activity, $\rho$ nitrophenyl- $\beta$-D-glucopyranoside ( $p N P G$ ) was used as the substrate.

Seven strains showing glucosidase activity in fermented soymilk at 12 and $24 \mathrm{~h}$ incubation period at $41^{\circ} \mathrm{C}$ are listed. $\beta$-glucosidase activity of the seven strains of lactic acid bacteria were isolated from local fermented foods in fermented soymilk during incubation period of 12 and $24 \mathrm{~h}$ is shown in Table 2. All the seven strains showed detectable levels of the enzyme activity when grown in soymilk. There was a significant difference $(p<$ 0.005 ) in the $\beta$-glucosidase activity over 12 , and $24 \mathrm{~h}$ of incubation for all strains. All the seven strains showed an increase in $\beta$-glucosidase activity up to $24 \mathrm{~h}$ followed by a decline as fermentation progressed (data not showed). The increase in $\beta$-glucosidase activity between 12 and 24 h was significant $(p<0.05)$ for with $L$. plantarum pentosus SMN 001, L. casei subsp. rhamnosus FNCC 098, L. casei subsp rhamnosus FNCC 099, L. casei subsp. rhamnosus FNCC 113, L. delbrueckii subsp. delbrueckii FNCC 045, L. plantarum SMN 025 and L. plantarum pentosus FNCC 235.

Table 2: $\beta$-glucosidase activity of seven lactic acid bacteria in fermented soymilk at 12 and $24 \mathrm{~h}$ of incubation at $41{ }^{\circ} \mathrm{C}^{\star}$

\begin{tabular}{llll}
\hline \multicolumn{1}{c}{ Microorganisms } & $\begin{array}{l}\text { Source of } \\
\text { fermented food }\end{array}$ & Incubation time & Unit of enzyme \\
\hline L. plantarum pentosus SMN 001 & Cassava (patilo) & 12 & $0.321 \pm 0.048^{\mathrm{b}}$ \\
& & 24 & $0.463 \pm 0.027^{\mathrm{d}}$ \\
L. plantarum SMN 025 & Bamboo shoot & 12 & $0.352 \pm 0.015^{\mathrm{c}}$ \\
& & 24 & $0.653 \pm 0.031^{\dagger}$ \\
L. plantarum pentosus FNCC 235 & Moromi soybean & 12 & $0.329 \pm 0.016^{\mathrm{b}}$ \\
& & 24 & $0.587 \pm 0.028^{\mathrm{e}}$ \\
L. casei subsp. rhamnosus FNCC 098 & Cassava (growol) & 12 & $0.354 \pm 0.012^{\mathrm{c}}$ \\
& & 24 & $0.648 \pm 0.053^{\dagger}$ \\
L. casei subsp. rhamnosus FNCC 099 & Cassava (gatot) & 12 & $0.287 \pm 0.013^{\mathrm{a}}$ \\
& & 24 & $0.472 \pm 0.025^{\mathrm{d}}$ \\
L.casei subsp. rhamnosus FNCC 113 & Tempeh & 12 & $0.327 \pm 0.011^{\mathrm{b}}$ \\
& & 24 & $0.486 \pm 0.028^{\mathrm{d}}$ \\
L.delbrueckii subsp.delbrueckii FNCC 045 & Yoghurt & 12 & $0.329 \pm 0.016^{\mathrm{b}}$ \\
& & 24 & $0.617 \pm 0.028^{\mathrm{e}}$ \\
\hline
\end{tabular}

${ }^{*}$ From means standard deviation of three duplicates for each sample

abcdef Values in a column with different letters are significantly different $(p \leq 0.05)$

One unit of enzyme is the amount of $\beta$-glucosidase that released 1 micromole of $\rho$-nitrophenyl- $\beta$-D-glucopyranoside ( $\rho$ NPG) from $\rho \mathrm{NPG}$ per $\mathrm{mL} / \mathrm{min}$ at $41^{\circ} \mathrm{C}$ 


\section{Changes of isoflavone content during fermentation with strains lactic acid bacteria were isolated from local fermented foods}

During fermentation of soymilk with strains lactic acid bacteria were isolated from local fermented foods exhibiting $\beta$-glucosidase activity, a concomitant enzymatic hydrolysis of isoflavone glucosides occurs, leading to changes in the concentration of all the isoflavone forms in soymilk. Table 3 show the changes in isoflavone concentration occurring in soymilk during $24 \mathrm{~h}$ fermentation with $L$. plantarum pentosus SMN 001, $L$. casei subsp. rhamnosus FNCC 098, L. casei subsp rhamnosus FNCC 099, L. casei subsp. rhamnosus FNCC 113, L. delbrueckii subsp. delbrueckii FNCC 045, L. plantarum SMN 025 and L. plantarum pentosus FNCC 235 respectively. All the seven microorganisms caused a significant increase $(p<0.05)$ in the concentration of isoflavone aglycones via the $\beta$-glucosidase catalysed hydrolysis of isoflavone glucoside conjugates. Contents of glucosides, malonylglucosides and acetylglucoside isoflavones decreased slightly, while contents of aglycone isoflavones increased high during $24 \mathrm{~h}$ of fermentation in the soymilk fermented with strains lactic acid bacteria were isolated from local fermented foods. However, a optimun increase in the content of the bioactive aglycone isoflavones was noted in soymilk after $24 \mathrm{~h}$ of fermentation. Simultaneously, the contents of glucoside isoflavones underwent the most significant reduction. During this fermentation period, with $L$. plantarum SMN 025, the high level reduced from $150.62 \mu \mathrm{g} / \mathrm{mL}$ (at $24 \mathrm{~h}$ ) to $142.58 \mu \mathrm{g} / \mathrm{mL}$ and with $L$. plantarum pentosus FNCC 235 , the lower level reduced from $150.62 \mu \mathrm{g} / \mathrm{mL}$ (at $24 \mathrm{~h}$ ) to $149.74 \mu \mathrm{g} / \mathrm{mL}$ respectively. A similar trend in the changes of these isoflavones was also found when soymilk was fermented with L. plantarum SMN 025 and L. casei subsp. rhamnosus FNCC 098.

Isoflavones content in soymilk fermented with $L$. plantarum SMN 025 and $L$. casei subsp. rhamnosus FNCC 098

Result HPLC chromatograms of isoflavones in soymilk fermentation of soymilk with $L$. plantarum SMN 025. Contents of glucosides, malonylglucosides and acetylglucoside isoflavones decreased slightly, while contents of aglycone isoflavones increased slightly during the first $12 \mathrm{~h}$ of fermentation in the soymilk fermented with L. plantarum SMN 025 and L. casei subsp. rhamnosus FNCC 098. During this fermentation period, the level reduced from $150.62 \mu \mathrm{g} / \mathrm{mL}$ (at $18 \mathrm{~h}$ ) to $145.74 \mu \mathrm{g} / \mathrm{mL}$ $(86 \%)$ and from $150.62 \mu \mathrm{g} / \mathrm{mL}$ (at $18 \mathrm{~h}$ ) to $145.94 \mu \mathrm{g} / \mathrm{mL}$, $(86 \%)$ respectively. A similar trend in the changes of these isoflavones was also found when soymilk was fermented with $L$. plantarum SMN 025 and $L$. casei subsp. rhamnosus FNCC 098. The changes in isoflavone concentration in relation to increasing bacteria population in soymilk during $24 \mathrm{~h}$ fermentation at $41^{\circ} \mathrm{C}$ with $L$. plantarum SMN 025 and $L$. casei subsp. rhamnosus
FNCC 098, the high level reduced from $150.62 \mu \mathrm{g} / \mathrm{mL}$ (at $24 \mathrm{~h}$ ) to $142.58 \mu \mathrm{g} / \mathrm{mL}(105 \%)$ and from $150.62 \mu \mathrm{g} / \mathrm{mL}$ (at $24 \mathrm{~h}$ ) to $144.71 \mu \mathrm{g} / \mathrm{mL}(95 \%)$, respectively, is shown in Figure 3 and 4 . Simultaneously, the contents of glucoside isoflavones underwent the most significant reduction. The maximum concentration of aglycones produced corresponded to the highest $\beta$-glucosidase activity and the maximum cell population of each microorganism. In general, the concentration of isoflavone aglycones increased and at the same time, the concentration of isoflavone glucosides were reduced during fermented soymilk. However, a seen increase in the content of the bioactive aglycone isoflavones was noted in soymilk after $24 \mathrm{~h}$ of fermentation was no significant change $(p>0.05)$ (data not shown).

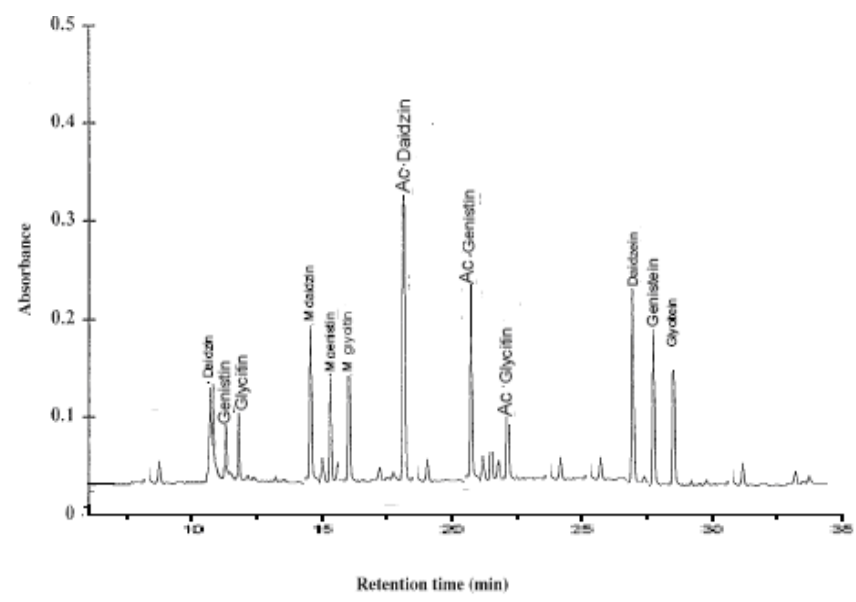

Figure 3: HPLC chromatograms of isoflavones in soymilk fermentation at $24 \mathrm{~h}$ of incubation at $41^{\circ} \mathrm{C}$ with L. plantarum SMN 025

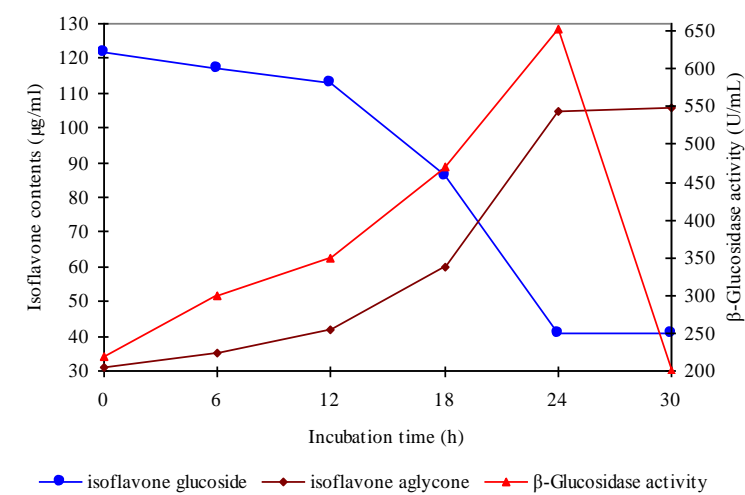

Figure 4: Changes in aglycone and glucoside isoflavone contents and $\beta$-glucosidase activity during the fermentation of soymilk with L. plantarum SMN 025 
Mal. J. Microbiol. Vol 6(1) 2009, pp. 30-40

Table 3: Isoflavone contents of various fermented soymilk ${ }^{*}$

\begin{tabular}{|c|c|c|c|c|c|c|c|c|}
\hline Isoflavone & Control & $\begin{array}{l}\text { L. plantarums } \\
\text { SMN } 025\end{array}$ & $\begin{array}{l}\text { Conte } \\
\text { L. plantarum } \\
\text { pentosus } \\
\text { SMN } 001\end{array}$ & $\begin{array}{l}\text { isoflavones }(\mu \mathrm{g} / \mathrm{m} \\
\text { L. plantarum } \\
\text { pentosus FNCC } \\
235\end{array}$ & $\begin{array}{l}\text { in soymilk ferm } \\
\text { L. casei subsp. } \\
\text { rhamnosus } \\
\text { FNCC } 098\end{array}$ & $\begin{array}{l}\text { ted with culture } \\
\text { L. casei subsp. } \\
\text { rhamnosus } \\
\text { FNCC } 099\end{array}$ & $\begin{array}{l}\text { L. casei subsp. } \\
\text { rhamnosus } \\
\text { FNCC } 113\end{array}$ & $\begin{array}{l}\text { L. delbrueckii } \\
\text { subsp. delbrueckii } \\
\text { FNCC } 045\end{array}$ \\
\hline \multicolumn{9}{|l|}{$\underline{\text { Glucoside }}$} \\
\hline Daidzin & $27.06 \pm 1.14^{\mathrm{a}}$ & $2.86 \pm 1.02^{b}$ & $15.97 \pm 1.12^{c}$ & $15.77 \pm 1.13^{c}$ & $3.56 \pm 1.01^{d}$ & $15.87 \pm 1.18^{c}$ & $15.86 \pm 1.16^{c}$ & $7.60 \pm 1.08^{\mathrm{e}}$ \\
\hline Genistin & $32.65 \pm 1.13^{\mathrm{a}}$ & $3.65 \pm 1.11^{b}$ & $11.42 \pm 1.10^{c}$ & $12.52 \pm 1.11^{\mathrm{c}}$ & $3.75 \pm 1.08^{b}$ & $12.52 \pm 1.14^{c}$ & $11.56 \pm 1.11^{\mathrm{c}}$ & $11.36 \pm 1.04^{d}$ \\
\hline Glycitin & $11.03 \pm 0.47^{\mathrm{a}}$ & $3.23 \pm 0.42^{\mathrm{b}}$ & $5.71 \pm 0.41^{c}$ & $5.93 \pm 0.37^{\circ}$ & $3.52 \pm 0.27^{b}$ & $5.73 \pm 0.24^{c}$ & $6.03 \pm 0.67^{c}$ & $8.13 \pm 0.44^{d}$ \\
\hline \multicolumn{9}{|c|}{ Malonylglucoside } \\
\hline Daidzin & $7.06 \pm 0.12^{\mathrm{a}}$ & $4.03 \pm 0.12^{b}$ & $7.47 \pm 0.15^{c}$ & $7.46 \pm 0.12^{c}$ & $4.26 \pm 0.12^{b}$ & $7.46 \pm 0.18^{c}$ & $6.96 \pm 0.12^{c}$ & $6.62 \pm 0.08^{d}$ \\
\hline Genistin & $5.65 \pm 0.14^{\mathrm{a}}$ & $3.45 \pm 0.11^{b}$ & $5.74 \pm 0.06^{c}$ & $5.75 \pm 0.31^{c}$ & $3.55 \pm 0.24^{b}$ & $5.75 \pm 0.14^{c}$ & $5.45 \pm 0.13^{c}$ & $4.35 \pm 0.10^{d}$ \\
\hline Glycitin & $3.03 \pm 0.12^{\mathrm{a}}$ & $2.03 \pm 0.08^{b}$ & $3.16 \pm 0.17^{\mathrm{a}}$ & $3.12 \pm 0.19^{\mathrm{a}}$ & $2.23 \pm 0.10^{b}$ & $3.14 \pm 0.22^{\mathrm{a}}$ & $3.13 \pm 0.14^{\mathrm{a}}$ & $2.19 \pm 0.12^{b}$ \\
\hline \multicolumn{9}{|c|}{ Acetylglucoside } \\
\hline Daidzin & $14.26 \pm 0.42^{a}$ & $10.26 \pm 1.12^{b}$ & $13.29 \pm 1.23^{\mathrm{a}}$ & $13.19 \pm 1.26^{a}$ & $11.62 \pm 1.02^{b}$ & $13.29 \pm 1.11^{\mathrm{a}}$ & $11.22 \pm 1.01^{\mathrm{b}}$ & $10.36 \pm 1.10^{b}$ \\
\hline Genistin & $12.56 \pm 0.74^{\mathrm{a}}$ & $7.16 \pm 0.78^{b}$ & $11.34 \pm 0.97^{c}$ & $11.05 \pm 0.57^{\mathrm{c}}$ & $7.45 \pm 0.84^{b}$ & $11.35 \pm 0.67^{\mathrm{c}}$ & $12.16 \pm 0.74^{c}$ & $8.86 \pm 0.76^{d}$ \\
\hline Glycitin & $9.33 \pm 0.31^{\mathrm{a}}$ & $4.33 \pm 1.02^{b}$ & $9.83 \pm 1.10^{\mathrm{a}}$ & $9.93 \pm 1.08^{\mathrm{a}}$ & $4.31 \pm 1.12^{b}$ & $9.93 \pm 1.14^{\mathrm{a}}$ & $10.34 \pm 1.06^{\mathrm{a}}$ & $5.53 \pm 1.11^{d}$ \\
\hline \multicolumn{9}{|l|}{ Aglycone } \\
\hline Daidzein & $15.16 \pm 0.32^{\mathrm{a}}$ & $42.70 \pm 1.12^{b}$ & $23.16 \pm 1.12^{c}$ & $23.26 \pm 1.12^{c}$ & $43.96 \pm 1.12^{b}$ & $23.16 \pm 1.12^{c}$ & $24.27 \pm 1.12^{\mathrm{c}}$ & $33.26 \pm 1.12^{d}$ \\
\hline Genistein & $8.46 \pm 0.44^{\mathrm{a}}$ & $34.61 \pm 0.74^{b}$ & $22.44 \pm 0.74^{c}$ & $22.15 \pm 0.74^{c}$ & $32.67 \pm 0.74^{b}$ & $22.25 \pm 0.74^{c}$ & $21.32 \pm 0.74^{c}$ & $29.86 \pm 0.74^{d}$ \\
\hline Glycitin & $4.37 \pm 0.13^{\mathrm{a}}$ & $24.27 \pm 1.12^{b}$ & $19.31 \pm 1.12^{c}$ & $18.92 \pm 1.12^{c}$ & $23.73 \pm 1.12^{b}$ & $19.31 \pm 1.12^{c}$ & $18.21 \pm 1.12^{c}$ & $19.83 \pm 1.12^{c}$ \\
\hline Total & $150.62 \pm 1.02$ & $142.58 \pm 0.60$ & $148.81 \pm 1.03$ & $149.05 \pm 1.01$ & $144.71 \pm 0.50$ & $149.74 \pm 1.08$ & $148.80 \pm 1.10$ & $147.95 \pm 0.30$ \\
\hline
\end{tabular}

* From means standard deviation of three duplicates for each sample

Means in the same row with different small letter superscripts are significantly different $(p<0.05)$

Fermented soymilk with sevens strains of lactic acid bacteria were isolated from local fermented foods were incubated at $41^{\circ} \mathrm{C}$ for $24 \mathrm{~h}$ 
Mal. J. Microbiol. Vol 6(1) 2009, pp. 30-40

Table 4: Changes in isoflavone content during the fermentation of soymilk with L. plantarum SMN $025^{*}$

\begin{tabular}{|c|c|c|c|c|c|}
\hline \multirow[t]{2}{*}{ Isoflavone } & \multicolumn{5}{|c|}{ Content of isoflavones $(\mu \mathrm{g} / \mathrm{mL})$ in fermented of soymilk was incubated at $41^{\circ} \mathrm{C}$} \\
\hline & $\mathbf{O h}$ & $6 \mathrm{~h}$ & $12 \mathrm{~h}$ & $18 \mathrm{~h}$ & $24 \mathrm{~h}$ \\
\hline \multicolumn{6}{|l|}{ Glucoside } \\
\hline Daidzin & $27.06 \pm 1.16^{\mathrm{a}}$ & $27.01 \pm 1.02^{\mathrm{a}}$ & $26.05 \pm 1.15^{\mathrm{b}}$ & $18.16 \pm 1.02^{\mathrm{C}}$ & $2.86 \pm 1.12^{d}$ \\
\hline Genistin & $32.65 \pm 1.14^{\mathrm{a}}$ & $32.55 \pm 1.24^{\mathrm{a}}$ & $32.45 \pm 1.16^{\mathrm{a}}$ & $12.65 \pm 1.14^{\mathrm{b}}$ & $3.65 \pm 1.14^{\mathrm{c}}$ \\
\hline Glycitin & $11.03 \pm 0.47^{\mathrm{a}}$ & $10.05 \pm 0.47^{\mathrm{a}}$ & $10.02 \pm 0.43^{a}$ & $9.03 \pm 0.47^{b}$ & $3.23 \pm 0.47^{c}$ \\
\hline \multicolumn{6}{|c|}{ Malonylglucoside } \\
\hline Daidzin & $7.06 \pm 0.12^{a}$ & $7.04 \pm 0.11^{a}$ & $6.09 \pm 0.09^{b}$ & $5.06 \pm 0.12^{\mathrm{C}}$ & $4.03 \pm 0.10^{d}$ \\
\hline Genistin & $5.65 \pm 0.14^{a}$ & $4.35 \pm 0.24^{a}$ & $4.15 \pm 0.16^{a}$ & $4.05 \pm 0.14^{a}$ & $3.45 \pm 0.14^{b}$ \\
\hline Glycitin & $3.03 \pm 0.12^{\mathrm{a}}$ & $3.83 \pm 0.10^{\mathrm{a}}$ & $3.03 \pm 0.11^{\mathrm{a}}$ & $2.83 \pm 0.12^{b}$ & $2.03 \pm 0.12^{c}$ \\
\hline \multicolumn{6}{|c|}{ Acetylglucoside } \\
\hline Daidzin & $14.26 \pm 0.42^{\mathrm{a}}$ & $13.86 \pm 1.12^{b}$ & $12.26 \pm 1.16^{\mathrm{C}}$ & $12.12 \pm 1.12^{c}$ & $10.26 \pm 1.12^{b}$ \\
\hline Genistin & $12.56 \pm 0.74^{\mathrm{a}}$ & $11.05 \pm 0.74^{b}$ & $10.32 \pm 0.54^{b}$ & $10.56 \pm 0.74^{b}$ & $7.16 \pm 0.74^{c}$ \\
\hline Glycitin & $9.33 \pm 0.31^{a}$ & $8.03 \pm 1.12^{b}$ & $8.63 \pm 1.11^{b}$ & $8.43 \pm 1.12^{b}$ & $4.33 \pm 1.12^{b}$ \\
\hline \multicolumn{6}{|l|}{ Aglycone } \\
\hline Daidzein & $15.16 \pm 0.32^{\mathrm{a}}$ & $16.26 \pm 1.12^{b}$ & $17.16 \pm 1.02^{C}$ & $30.76 \pm 1.18^{d}$ & $44.70 \pm 1.12^{\mathrm{e}}$ \\
\hline Genistein & $8.46 \pm 0.44^{\mathrm{a}}$ & $10.56 \pm 0.74^{b}$ & $11.26 \pm 0.64^{b}$ & $20.16 \pm 0.74^{c}$ & $34.61 \pm 0.74^{d}$ \\
\hline Glycitin & $4.37 \pm 0.13^{\mathrm{a}}$ & $5.33 \pm 1.12^{\mathrm{a}}$ & $6.53 \pm 0.92^{b}$ & $11.93 \pm 1.12^{\mathrm{C}}$ & $24.27 \pm 1.12^{d}$ \\
\hline Total & $150.62 \pm 5.43$ & $149,92 \pm 4.52$ & $147,95 \pm 4.34$ & $145,74 \pm 3.21$ & $142.58 \pm 3.13$ \\
\hline
\end{tabular}

* From means standard deviation of three duplicates for each sample

abcde Means in the same row with different small letter superscripts are significantly different $(p<0.05)$

Fermented soymilk containing L. plantarum SMN 025 was incubated at $41^{\circ} \mathrm{C}$ for $24 \mathrm{~h}$

Table 5: Changes in isoflavone content during the fermentation of soymilk with L. casei subsp. rhamnosus FNCC $098^{*}$

\begin{tabular}{|c|c|c|c|c|c|}
\hline \multirow[t]{2}{*}{ Isoflavone } & \multicolumn{5}{|c|}{ Content of isoflavones $(\mu \mathrm{g} / \mathrm{mL})$ in fermented of soymilk was incubation at $41^{\circ} \mathrm{C}$} \\
\hline & $\mathbf{O h}$ & $6 \mathrm{~h}$ & $12 \mathrm{~h}$ & $18 \mathrm{~h}$ & $24 \mathrm{~h}$ \\
\hline \multicolumn{6}{|l|}{ Glucoside } \\
\hline$\overline{\text { Daidzin }}$ & $27.06 \pm 1.12^{\mathrm{a}}$ & $27.01 \pm 1.02^{\mathrm{a}}$ & $25.05 \pm 1.15^{\mathrm{b}}$ & $18.16 \pm 1.22^{\mathrm{C}}$ & $3.56 \pm 0.12^{d}$ \\
\hline Genistin & $32.65 \pm 1.14^{\mathrm{a}}$ & $32.55 \pm 1.24^{\mathrm{a}}$ & $32.25 \pm 1.16^{\mathrm{a}}$ & $12.65 \pm 1.04^{b}$ & $3.75 \pm 0.14^{\mathrm{c}}$ \\
\hline Glycitin & $11.03 \pm 0.47^{\mathrm{a}}$ & $10.05 \pm 0.47^{b}$ & $10.02 \pm 0.43^{b}$ & $9.03 \pm 0.37^{c}$ & $4.52 \pm 0.47^{d}$ \\
\hline \multicolumn{6}{|c|}{ Malonylglucoside } \\
\hline Daidzin & $7.06 \pm 0.12^{a}$ & $7.04 \pm 0.11^{\mathrm{a}}$ & $6.09 \pm 0.09^{b}$ & $5.06 \pm 0.13^{c}$ & $5.26 \pm 0.17^{d}$ \\
\hline Genistin & $5.65 \pm 0.14^{a}$ & $4.35 \pm 0.24^{b}$ & $4.15 \pm 0.16^{b}$ & $4.05 \pm 0.14^{b}$ & $4.25 \pm 0.14^{b}$ \\
\hline Glycitin & $3.03 \pm 0.12^{\mathrm{a}}$ & $3.83 \pm 0.10^{b}$ & $3.03 \pm 0.11^{\mathrm{a}}$ & $2.83 \pm 0.11^{\mathrm{b}}$ & $2.53 \pm 0.12^{b}$ \\
\hline \multicolumn{6}{|c|}{ Acetylglucoside } \\
\hline Daidzin & $14.26 \pm 0.42^{\mathrm{a}}$ & $13.76 \pm 1.12^{b}$ & $13.26 \pm 1.16^{b}$ & $12.12 \pm 1.10^{c}$ & $11.62 \pm 1.12^{d}$ \\
\hline Genistin & $12.56 \pm 0.74^{\mathrm{a}}$ & $11.05 \pm 0.74^{b}$ & $11.32 \pm 0.54^{b}$ & $10.56 \pm 0.79^{c}$ & $9.45 \pm 0.74^{d}$ \\
\hline Glycitin & $9.33 \pm 0.31^{a}$ & $8.03 \pm 1.12^{b}$ & $8.63 \pm 1.11^{b}$ & $11.43 \pm 1.13^{\mathrm{C}}$ & $4.31 \pm 0.12^{d}$ \\
\hline \multicolumn{6}{|l|}{ Aglycone } \\
\hline$\overline{\text { Daidzein }}$ & $15.16 \pm 0.32^{\mathrm{a}}$ & $16.26 \pm 1.12^{b}$ & $17.16 \pm 1.02^{c}$ & $30.76 \pm 1.18^{d}$ & $41.96 \pm 2.12^{\mathrm{e}}$ \\
\hline Genistein & $8.46 \pm 0.44^{a}$ & $10.46 \pm 0.74^{b}$ & $11.26 \pm 0.64^{b}$ & $19.26 \pm 0.94^{c}$ & $32.77 \pm 1.74^{d}$ \\
\hline Glycitin & $4.37 \pm 0.13^{\mathrm{a}}$ & $5.33 \pm 1.12^{\mathrm{a}}$ & $6.43 \pm 0.92^{b}$ & $9.93 \pm 1.02^{c}$ & $20.73 \pm 1.52^{d}$ \\
\hline Total & $150.62 \pm 5.32$ & $149.72 \pm 4.12$ & $148.65 \pm 4.31$ & $145.94 \pm 3.23$ & $144.71 \pm 3.15$ \\
\hline
\end{tabular}

\footnotetext{
* From means standard deviation of three duplicates for each sample

abcde Means in the same row with different small letter superscripts are significantly different $(p<0.005)$. Fermented soymilk containing $L$. casei subsp. rhamnosus FNCC 098 was incubated at $41^{\circ} \mathrm{C}$ for $24 \mathrm{~h}$
} 


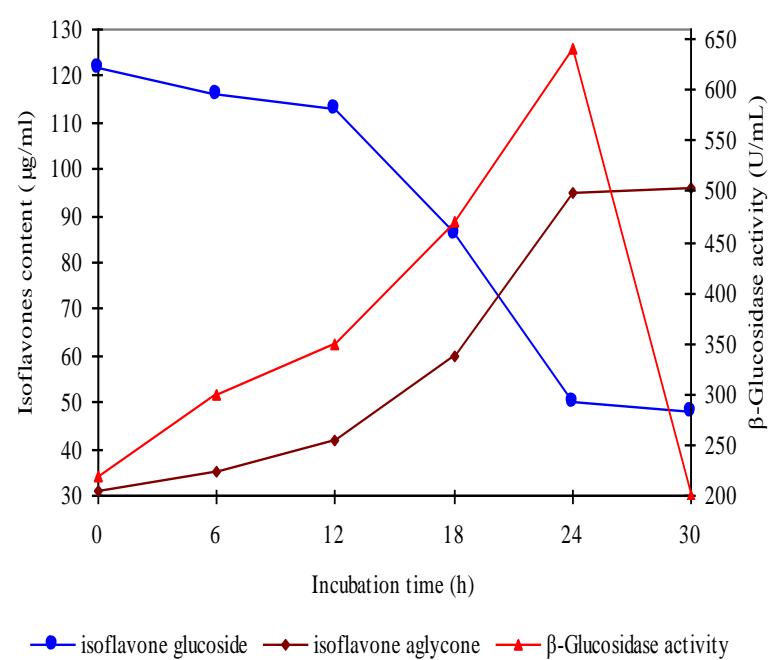

Figure 5: Changes in aglycone and glucoside isoflavone contents and $\beta$-glucosidase activity during the fermentation of soymilk with $L$. casei subsp. rhamnosus FNCC 098

Changes of $\beta$-glucosidase activity, aglycone and glucoside isoflavone contents during fermentation

Changes in the content of $\beta$-glucosidase activity, isoflavone glucosides and aglycones in soymilk fermented with L. plantarum SMN 025 and L. casei subsp. rhamnosus FNCC 098 showed in Figure 4 and 5, respectively. Decrease in the concentration of isoflavone glucosides with a corresponding significant increase in the concentration of isoflavone aglycones during incubation with $L$. plantarum SMN 025 and $L$. casei subsp. rhamnosus FNCC 098. Activity of $\beta$-glucosidase in soymilk fermented with $L$. plantarum SMN 025 and $L$. casei subsp. rhamnosus FNCC 098 exhibited the highest of $0.653 ; 0.643 \mathrm{U} / \mathrm{mL}$ respectively. In addition, changes of glucoside and aglycone isoflavone contents expressed as a percent of total isoflavone, obtained by dividing the content of individual isoflavone with total isoflavones. The highest $\beta$-glucosidase activity in the $L$. plantarum SMN 025 and L. casei subsp. rhamnosus FNCC 098 fermented in soymilk increase in the concentration of isoflavone aglycones. There appeared to be correlations between the level of cell population and $\beta$-glucosidase activity of each strain, and the hydrolysis of conjugated isoflavones in soymilk fermentation. The observed phenomenon was in agreement with the reports of Esaki et al. (1994) and Choi, et al. (2002). Wang et al. (2006) reported that fermentation with lactic acid bacteria and bifidobacteria, individually and in combination, increased the antioxidative activity of soymilk.

\section{CONCLUSIONS}

Seven strains of bacteria, L. plantarum pentosus SMN 001, L. casei subsp. rhamnosus FNCC 098, L. casei subsp. rhamnosus FNCC 099, L. casei subsp. rhamnosus FNCC 113, L. delbrueckii subsp. delbrueckii FNCC 045, L. plantarum SMN 025, and L. plantarum pentosus FNCC 235 exhibited variable $\beta$-glucosidase activity. $L$. plantarum SMN 025, L. casei subsp rhamnosus FNCC 098 exhibited the highest $\beta$-glucosidase activity of $0.653 ; 0.643 \mathrm{U} / \mathrm{mL}$ respectively. Seven $\beta$-glucosidase-producing strains are able to increase aglycones in fermented soymilk, however, each of the strain produces significantly different bioconversion $(p<0.05)$ of the glucoside isoflavones into their bioactive aglycones. During this fermentation period, with L. plantarum SMN 025, and L. casei subsp. rhamnosus FNCC 098, the high level reduced from $150.62 \mu \mathrm{g} / \mathrm{mL}$ (at $24 \mathrm{~h}$ ) to $142.58 \mu \mathrm{g} / \mathrm{mL}$ and from 150.62 $\mu \mathrm{g} / \mathrm{mL}$ (at $24 \mathrm{~h}$ ) to $144.71 \mu \mathrm{g} / \mathrm{mL}$, respectively. The present study indicates that two $\beta$-glucosidase producing lactic acid bacteria has great potential for enrichment of bioactive isoflavones in soymilk fermentation.

\section{ACKNOWLEDGEMENT}

The author would like to thank the Indonesian Institute of Sciences and the Centre for Food and Nutrition Studies, Gadjah Mada University for an excellent collaboration and Prof. Ferry Sandra for helpful discussions.

\section{REFERENCES}

Bordignon, J. R., Nakahara, K., Yoshihashi, T. and Nikkuni, S. (2004). Hydrolysis of isoflavone and consumption oligosaccharides during lactic acid fermentation of soybean, Food and Technology Division, (JIRCAS), Tsukuba, Ibaraki 305-8686, Japan. http://www.Jircas.affrc.go.jp

Brouns, F., (2002). Soya isoflavones: A new and promising ingredient for the health food sector. Food Research International 35, 187-193.

Brown, J.P., (1988). Hydrolysis of glycosides and esters. In: Role of the gut flora in toxicity and cancer. Rowland R. (ed.). Academic Press, San Diego, CA, pp. 109-144.

Chien, H. L., Huang, H. Y. and Chou, C. C. (2006). Transformation of isoflavone phytoestrogens during the fermentation of soymilk with lactic acid bacteria and bifidobacteria. Journal of Food Microbiology 23, 772-778.

Choi, Y. B., Kim, K. S. and Rhee, J. S. (2002). Hydrolysis of soybean isoflavone glucosides by lactic acid bacteria. Journal Biotechnology 24, 2113-2116.

Coward, L., Smith, M., Kirk, M., \& Barnes, S. (1998). Chemical modification of isoflavones in soyfoods during cooking and processing. American Journal of Clinical Nutrition 68, 1486S-1491S.

Esaki, H., Watanabe, R., Hishikawa, N., Osawa, T., and Kawakishi, S. (2004). Utility of isoflavone 
preparations from soy sauce cake as antioxidant materials. Journal of Japan Society, Food Science Technology 51, 47-53.

Fukutake, M., Takahshi, M. and Ishida, K. (1996). Quantification of genistein and genistin in soybeans and soybean products. Journal Food Chemistry and Toxicology 34, 457-461.

Food and Drug Administration (1999). Food labeling, health claims, soy protein, and coronary heart disease. Food and Drug Admin., 21 Code of Federal Regulations, Part 101, Oct 26.

Gerhauser, C., Klimo, K., Heiss, E., Neumann, I., Gamal-Eldeen, A., Knauft, J., Liu, G. Y., Sitthimonchai, S. and Frank, N. (2003). Mechanism-based in vitro screening of potential cancer chemopreventive agents. Journal of Mutation Research 524, 163-172.

Hargreves, D. F., Potten, C. S., Harding, C., Shaw, L. E., Morton, M. S., Roberts, B.A., Hawell, A. and Bundred, N. J. (1999). Two-week dietary soy supplementation has an estrogenic effect on normal premenopause breast. Journal of Clinical Endocrinology Metabolism 84, 4017-4024.

Hermansen, K., Dinesen, B., Hoie, L. H., Morgenstern, E. and Gruenwald, J. (2003). Effects of soy and other natural products on LDL:HDL ratio and other lipid parameters: A literature review. Journal of Advisior Theraphy 20, 50-78.

Jacobsen, B. K., Knutsen, S. F. and Fraser, G. E. (1998). Does high soy milk intake reduce prostate cancer incidence. The Adventist Health Study (United States). Journal of Cancer Causes Control 9, 553557.

King, R. A. and Bignell, C. M. (2000). Concentration of isoflavone phytoestrogens and their glucosides in Australian soya beans and soya foods. Australian Journal of Nutrition and Dietetics, 57, 70-78.

Liggins, J., Bluck, L. J., Runswick, S., Atkinson, C., Coward, W. A. and Bingham, S. A. (2000). Daidzein and genistein contents of vegetables. Journal of Nutrition, 84, 717-725.

Matsuda, S., Norimoto, F., Matsumoto, Y., Ohba, R., Teramoto, Y., Ohta, N. and Ueda, S. (1994). Solubilization of a novel isoflavone glucosidehydrolyzing $\beta$-glucosidase from Lactobacillus casei subsp. rhamnosus. Journal of Fermentation Bioengineering 77, 439-441.

Matsuura, M., and Obata, A. (1993). $\beta$-Glucosidases from soybeans hydrolyze daidzin and genistin. Journal of Food Science 58, 144-147.

Mastuura, M., Obata, A., \& Fukushima, D. (1998). Objectionable flavor of soymilk developed during soaking of soybeans and its control. Journal of Food Science 54, 602-607.

Messina, M., Gugger, E. T. and Alekel, D. L. (2001). Soy protein, soybean isoflavones, and bone health: A review of the animal and human data. In: Handbook of nutraceuticals and functionl foods. Wildman, R. (ed.). CRC Press, Boca Raton, FL. pp. 77-98.
Murphy, P. A., Barua, K. and Hauck, C. C. (2002). Solvent extraction selection in the determination of isoflavones in soy foods. Journal of Chromatography B 777, 129-138.

Omoni, A. O. and Aluko, R. E. (2005). Soybean foods and their benefits: Potential mechanisms of action. Journal of Nutrition 63, 272-283.

Pandjaitan, N., Hettiarachchy, N. and Ju, Z., Y. (2000a). Enrichment of genistein in soy protein concentrate with beat $\beta$-glucosidase. Journal Food Science 65, 403-407.

Pandjaitan, N., Hettiarachchy, N., Ju, Z. Y., Crandall, P., Seneller, C. and Ombek, D. (2000b). Enrichment of Genistein in soy protein concentrate with hydrocolloids and $\beta$-glucosidase. Journal Food Science 65, 591-595.

Park, Y. K., Aguiar, C. L., Alencar, S. M., Mascrenhas, H. A. A. and Scamparini, A. R. P. (2002). Conversion of malonyl B-glucoside isoflavones into glycoside isoflavones found in some cultivars of Brazilian soybeans. Journal of Science Technology Alimentacion, 22, 130-135.

Park, Y. K., Lui, M. C. Y. and Aguiar, C. L. (2003). Production of enriched isoflavone aglycones during processing of soy protein isolates and soy protein concentrates. In: 2003 IFT Annual Meeting Book of Abstracts. 12 - 16 July 2003. Institute of Food Technologists, Chicago, IL. pp. 215.

Pyo, Y. H., Lee, T. C. and Lee, Y. C. (2005). Enrichment of bioactive isoflavones in soymilk fermented with $\beta$ glucosidase-producing lactic acid bacteria. Journal of Food Research International 38, 551-559.

SAS (2001). SAS User's Guide: Statistics (8.01 Ed.). SAS Institute Inc., Cary, NC.

Scalabrini, P., Rossi, M., Spettoli, P., \& Matteuzi, D. (1998). Characterisation of Bifidobacterium stains for use in soymilk fermentation. Internal Journal of Food Microbiology 39, 213-219.

Setchell, K. D. R. (1998). Phytoestrogens: the biochemistry, physiology, and implications for human health of soy isoflavones. American Journal of Clinical Nutrition 68, 1333S-1346S.

Setchell, K, D. R., Brown, N. M., Zimmer-Nechemias, L., Brashear, W. T., Wolfe, B. E., Kirschner, A. S. and Heubi, J. E. (2002). Evidence for lack of absorption of soy isoflavone glycosides in humans, supporting the crucial role of intestinal metabolism for bioavailability. American Journal of Clinical Nutrition 76, 447-453.

Sumarna. (2008). Changes of raffinose and stachyose in soy milk fermentation by lactic acid bacteria from local fermented foods of Indonesian. Malaysian Journal of Microbiology 4(2), 26-34.

Tochikura, T., Sakai, K., Fujiyoshi, T., Tachiki, T., and Kumagai, H. (1986). Para-nitrophenyl glycosidehydrolyzing activities in bifidobacteria and characterization of beta-galactosidase of Bifidobacterium longum 401. Journal Agricultural and Biological Chemistry 50(9), 2279-2286. 
Tsangalis, D., Ashton, J. F., McGill, J. and Shah, N. P. (2002). Enzymatic transformation of isoflavone phytoestrogens in soymilk by $\beta$-glucosidase producing bifidobacteria. Journal of Food Science 67, 3104-3113.

Tsangalis, D., Ashton, J. F., McGill, A, E. J. and Shah, N. P. (2003). Biotransformation of isoflavones by bifidobacteria in fermented soymilk supplemented with D-glucose and L-cysteine. Journal of Food Science 68, 623-631.

Wang HJ, Murphy PA. (1994) Isoflavone content in commercial soybean foods. Journal of Agricultural and Food Chemistry 42, 1666-1673.

Wang, H. J. and Murphy, P. A. (1996). Mass balance study of isoflavones during soybean processing. Journal of Agricultural and Food Chemistry 44, 2377 2383.

Wang, Y. C., Yu, R. C., Yang, H. Y. and Chou, C. C. (2003). Sugar, acid and B-vitamin contents in soymilk fermented with lactic acid bacteria alone or simultaneously with bifidobacteria. Journal of Food Microbiology 20, 333-338.

Wang, Y. C., Yu, R. C. and Chou, C. C. (2006). Antioxidative activities of soymilk fermented with lactic acid bacteria and bifidobacteria. Journal of Food Microbiology 23, 128-135.

Xu, X., Wang, H. J. and Murphy, P. A. (1994). Daidzein is a more bioavailable soymilk isoflavone than genistein in adult woman. Journal of Nutrition 124, 825-832. 